\title{
Governing Conflicts between Mining and Tourism in the Arctic
}

\author{
Jukka Similä \\ University of Lapland ${ }^{1}$
}

\section{Mikko Jokinen}

Natural Resource Institute Finland LUKE

\begin{abstract}
The Arctic is one of the largest regions on the globe, and is regarded as a vast storehouse of potential resources, including minerals. Both mining and tourism are rapidly growing economic sectors in the region. While the variety of tourism activities supported and offered is extensive, all of these activities are essentially forms of nature-based tourism.

Land-use conflicts between mining and tourism are likely to emerge when a new mine is opened close to a tourist area, because mining activities may dramatically change the landscape, which is essential for tourism. The impact greatly depends on the location of mining facilities, the physical size of the mining project, the mining processes used, logistics and how well the image of the mine and its end product fits in with the image of the tourist destination. While tourism and the mining industry may benefit from each other, the relationship between a mine and tourism is often asymmetrically counterproductive; where such a relationship exists, a need for regulation arises.

In this article, we assess the legal means available for resolving conflicts between the mining and tourism industries and discuss possibilities to improve these means. The two key regulatory instruments for governing such conflicts are land-use planning and mining permit processes. We illustrate the nature of conflicts and various decision-making procedures with reference to the Finnish legal framework and a case study on an ongoing mining project in the town of Kolari.
\end{abstract}

Keywords: law, conflict, mining, tourism, land-use planning, mining law

Responsible Editor: Margherita Paola Poto, UiT - The Arctic University of Norway, Tromsø, Norway.

Received: November 2017; Accepted: April 2018; Published: June 2018

\footnotetext{
^Correspondence to: Jukka.Simila@ulapland.fi

(C) 2018 Jukka Similä \& Mikko Jokinen. This is an Open Access article distributed under the terms of the Creative Commons Attribution-NonCommercial 4.0 International License (https://creativecommons.org/licenses/by-nc/4.0/), allowing third parties to share their work (copy, distribute, transmit) and to adapt it, under the condition that the authors are given credit, that the work is not used for commercial purposes, and that in the event of reuse or distribution, the terms of this license are made clear. Arctic Review on Law and Politics,Vol. 9, 2018, pp. 148-173. http://dx.doi.org/10.23865/arctic.v9.1068
} 


\section{Introduction}

The Arctic is one of the largest regions on the globe, and is regarded as a vast storehouse of potential resources. Several recent international evaluations place the Arctic region, including northern Finland, among the most favored areas for targeting mining operations globally. ${ }^{2}$ Mining, however, is a controversial activity. While people all over the world need minerals and the products made from them, mining may also cause significant negative impacts on the surrounding social and ecological environments. Benefits are realized and costs incurred at different levels, from local to global. The supply of raw materials is ultimately a global issue, although mineral extraction may produce significant economic benefits for the society at the local and regional levels or even at the national level through job creation and increased tax revenue.

Mining may negatively affect surrounding communities and the environment in many different ways. ${ }^{3}$ It often takes place in remote areas, where the livelihoods of the communities are nature-based, making it difficult to differentiate the detrimental impacts of mining on communities from those on the environment. This applies, for example, in the case of the indigenous Saami of northernmost Europe, who are engaged in reindeer herding, fishing and hunting, as well as other local residents. Mining may also cause tensions with competing modern industrial uses of the natural environment, ${ }^{4}$ although this depends on the nature of the industry concerned. Forestry is still the largest economic sector in northern Finland, but there are no land-use conflicts between forestry and mining, as mining activities only require comparatively small land areas and thus have a minimal impact on forestry operations. ${ }^{5}$ In northern Finland, as in many other Arctic regions, another rapidly growing modern industry is tourism, which is more sensitive than forestry to the impacts of mining. While the variety of tourism activities in the Arctic is extensive, in practice they are all different forms of nature-based tourism. Land-use conflicts between nature-based tourism and mining may emerge particularly when a new mine is opened close to a tourism area. The benefits of mining for the local economy may be significantly reduced if mining causes a flourishing tourism industry in the region to decline.

In response to what is a booming mining industry in the Arctic, legal scholars have explored mining law in general, ${ }^{6}$ the environmental control of mining activities ${ }^{7}$ and the relationship between mining and indigenous peoples. ${ }^{8}$ The Finnish legal literature features articles that focus on land-use conflicts between mining and tourism in the country, ${ }^{9}$ but papers in English that address international audiences are rare. In this article, we assess the legal means available for resolving conflicts between mining and tourism. We illustrate the nature of such conflicts and various decision-making procedures with reference to the Finnish legal framework and a case study on an ongoing mining project in the town of Kolari.

The rest of the article is divided into four main sections. The first presents a theoretical discussion of when the relationship between mining and tourism is 


\section{fukka Similä E̋ Mikko fokinen}

complementary and when it is counterproductive. In the section that follows we go on to describe the relationship between the two industries in an ongoing Finnish case to concretize what kinds of facts and uncertainties decision-makers face prior to final public policy decisions. In analyzing the case, we use a literature review, legal analysis and survey results on the Hannukainen mining project and other land-use projects. We then proceed with a section analyzing the key legal instruments for the regulation of landscape impacts of mining in Finland, namely, land-use planning and mining law. In the closing section, we summarize regulatory challenges and discuss how regulation might be improved.

\section{The mining and tourism industries}

\subsection{Mining and tourism - complementary or counterproductive industries?}

Mining and tourism both rely on products and services provided by nature, that is, natural resources or ecosystem services. The relationship between various ways of consuming natural resources can be rival, non-rival, partially rival or complementary. If modes of consuming resources are rival, consumption of a resource by one actor reduces the possibilities for consumption by others. If the relationship is non-rival, then a new consumer has equal opportunities to use the resource even if it is already being used by others. A complementary relationship exists when one type of natural resource consumption creates possibilities for other types. The case may also be that the relationship is partially rival, meaning that the rate and degree of rivalry vary. The consumption of one environmental resource may preclude consumption of another only after the consumption has reached a certain degree or rate. ${ }^{10}$ As a mineral deposit can be used only once, mining companies are in rival relations with each other. Different tourism companies can use similar environmental resources in parallel, and only when there are too many companies - or clients using the same green infrastructure, does a rival relationship emerge. In such cases, the relationship is partially rival.

The relationship between mining and tourism is contextual: it can be rival, nonrival, partially rival or complementary depending on factors such as the locations of activities, landscape and types of mining or tourism. Generally speaking, one can assume that these two industries do not compete with each other for common resources and, consequently, can develop independently - or even have a complementary relationship. A tourist resort located nearby a a mine may benefit from the location, because miners and their families are likely to be interested in services provided by the resort, such as stores, restaurants and entertainment. Mining often takes place in remote areas and the accessibility of services provided by a tourist destination close to a mine may make jobs at the mine more attractive to potential employees.

In certain circumstances, the relationship between a mine and a tourism destination may be asymmetrically counterproductive, an example being when the destination suffers from environmental impacts (externalities) caused by the mining. 
These impacts can take many forms, such as changes in the landscape, pollution of waterways, noise or a combination of these. How significant the consequences are depends not only on the size of impacts but also the nature of the tourism business involved. In the case of industrial tourism, the destination may be an industrial site or even a mine that is unique to a particular location. In such an instance, the environmental impacts of an active mine may not necessarily have any business impacts on tourism. However, various forms of nature-based tourism tend to be sensitive to significant environmental impacts of mining and other large-scale industrial activities. There is no strict scientific definition of nature-based tourism but the concept usually refers to tourism where natural features such as landscapes, quality of nature and natural phenomena are key attractions and reasons why consumers visit a particular destination. ${ }^{11}$ The relationship is asymmetrical, because a mine will only benefit from the neighboring touristic attractions and services, whereas a nature-based tourism business may suffer significantly if it is located in the vicinity of a mine. This is particularly the case if the business idea is to sell tranquility and pristine nature, that is, an environment where clients can engage in outdoor activities in areas undisturbed by noise, destroyed landscapes or perceivable pollution. It is also possible that a mine is a tourist attraction, although this is rare. Such mines tend to be old and the mining methods historical, and this activity can be considered a form of heritage tourism. ${ }^{12}$ Typically, public access to operating mines is strictly prohibited for safety reasons.

Asymmetrical relationships indicate that the only problematic situations are where investments in tourism infrastructure precede mining or are growing significantly. If mining comes first, then new entrepreneurs can adapt their business plans to the fact that mining is already there. After investments in tourism infrastructure, tourism entrepreneurs expect that the landscape and other environmental resources crucial to their business will remain untouched. However, environmental resources such as the landscape are not property owned by the tourism industry. How mining or other developments shape the landscape largely depends on public policies. All industries, including tourism and mining, expect public policies to be predictable and to create stable conditions for businesses. Tourism and mining may, however, interpret the practical consequences of these expectations in different ways. The tourism industry clearly expects public policies to ensure that no detrimental changes in the landscape will occur, whereas the mining industry obviously expects public policies to allow the changes needed in the landscape.

\section{Case study: Hannukainen}

In 2005, during the mining boom in Lapland, the company Northland Resources Inc. (later Northland Mines Inc.) announced plans to open an iron mine in Kolari, a town in Finnish Lapland near the Swedish border. An iron mine operated in the same location between 1978 and 1990. At that time, the company operating the mine was the state-owned Rautaruukki, which could not make the mine profitable. ${ }^{13}$ The amount 


\section{fukka Similä E̋ Mikko fokinen}

of ore to be extracted at the new mine, including copper and gold, was projected to be 4.6 million tons. ${ }^{14}$ The facility would have an open pit 2.5 kilometers in diameter (the old pit was 600 meters wide). Estimated ore reserves at the site are 136 million tons for iron, copper and gold combined. The volume of waste rock and soil to be removed would be some 435 million tons ${ }^{15}$ (Tukes 2016). The old Hannukainen mine was totally different in scale when compared to the one in the new project plan (Table 1).

Northland Mines Ltd. went bankrupt in 2014 and a new mining company, Hannukainen Mining Ltd., took over the project. According to Hannukainen Mining, the lifespan of the mine will be between 17 to 25 years, including construction and it will create about 350 direct jobs in the area. ${ }^{16}$ However, critics of the project have questioned the figures on its economic and technical feasibility and have identified many environmental risks ${ }^{17}$

Table 1. Comparison of the old (1978-1990) and planned Hannukainen mines.

\begin{tabular}{lllll}
\hline & Planned $^{18}$ & Old $^{19}$ & $\begin{array}{l}\text { Old compared to } \\
\text { planned \% }\end{array}$ & $\begin{array}{l}\text { Difference in size } \\
\text { (times) }\end{array}$ \\
\hline Size of claim km ${ }^{2}$ & 22 & 1.1 & $5.0 \%$ & 20 \\
Amount of ore (million tons) & 115 & 4.6 & $4.0 \%$ & 25 \\
\hline Waste rock (million tons) & 435 & 5.4 & $1.2 \%$ & 81 \\
\hline
\end{tabular}

In the 1990s the volume of the tourism industry in the municipality of Kolari was low in comparison to what it is now. In two decades the number of visitors has doubled. ${ }^{20}$ Within the municipality of Kolari, tourism is strongly concentrated at the Ylläs tourist destination, which is adjacent to Finland's most popular national park, PallasYllästunturi. ${ }^{21}$ Growth was especially rapid in the 2000s. In short, the structure of the local economy has changed significantly in the municipality, a community with a population of 3,800 that sees more than 330,000 tourist overnights annually. This development can be attributed in part to the support of local authorities; for example, local land-use planning has been carried out from the perspective of the tourism industry. Another contributing factor has been public and private investments in the Ylläs and Levi ski resorts, which amounted to some EUR 1000 million in the period 20002009. Of these investments only 3 percent was state money, which took the form of business subsidies and aid for developing roads, water supplies and the environment. ${ }^{22}$

In 2014, Northland Resources and the parent company of Northland Mines, went bankrupt. This took place before any final decision was made regarding municipal level land-use plans, a mining permit or an environmental permit. After bankruptcy, mining rights were sold to a new company, Hannukainen Mining Ltd., which is owned by local Finnish entrepreneurs. After this change, in 2017, the municipality started preparing land-use plans and the new company submitted applications for an environmental permit and made changes to the mining patent application, originally submitted by the old company in 2010. In autumn 2017, the mining patent was granted; the application for an environmental permit is still being processed. 
After the announcement of the plans of Northland Mines in 2006, other land users, such as tourism entrepreneurs and reindeer herders, did not publicly protest. At least there are no documents showing that they did. The situation changed in 2013, when the first studies and environmental impact assessment were published. ${ }^{23}$ These revealed plans for extracting 25 times more ore and 81 times more waste rock and loose soil than were extracted in the 1980s (Table 1). Rather soon tourism enterprises and second-home owners mobilized and started an anti-Hannukainen campaign, aiming to submit a petition against the mine. The petition has over 46,000 signatures (March, 2018). Local tourism entrepreneurs and residents of the municipality close to Ylläs have also started a fundraising campaign to hire experts in the struggle against the mining project, a project to which the municipality is strongly committed. ${ }^{24}$

Survey studies conducted among tourists indicate that nature is the major attraction in Kolari and in Lapland generally. ${ }^{25}$ Beautiful landscapes, silence, a clean environment and a wealth of recreational opportunities are the key elements that draw domestic visitors and foreign tourists in particular to the area. In short, tourism in Ylläs is nature-based and anchored in the quality of the local environment as well as in the human and ecosystem services available.

For tourism the critical question is whether visitors will come back if the mine is established. This is especially important in Ylläs, a tourist destination where customers are extremely loyal. Studies show that most domestic customers have visited Ylläs at least five times and half of them have been there more than ten times. ${ }^{26}$

Research also shows that both customers (tourists) and producers (tourism companies) see many risks and problems associated with the Hannukainen mining project. A total of 44 percent of visitors think that interest in visiting Ylläs again would diminish if Hannukainen were built. Eighty percent think the mine would detract from the image of Ylläs as a nature-based destination. Negative impacts on the environment were identified by 87 percent of visitors, and 79 percent anticipated negative impacts on the resort's image as a wilderness area. ${ }^{27}$ Tourism entrepreneurs viewed the situation as being even worse. The mine would be located (on average) 9 kilometers from the tourism companies' activities while the tourism companies think that it should be at least 45 kilometers away. Entrepreneurs fear the worst where tourism is concerned, with 87 percent thinking that customers would reduce return visits or not come back at all. Moreover, 74 percent of entrepreneurs believe that if opened the mine would reduce their revenue or cause them to suspend investments (65 percent). ${ }^{28}$

The Hannukainen mine may also have negative impacts on tourism beyond the Ylläs destination. The processes at iron ore mines use several chemicals, such as xanthates, which are lethal to fish and micro-organisms in water. ${ }^{29}$ The mine plans to pump its processed waste waters straight into the Tornio-Muonio River (Figure 1), which is an important salmon fishing river and part of the Natura 2000 protection network. Expert statements suggest that residues in waste waters or leakages from the ore-processing area may pose major environmental risks in Arctic 


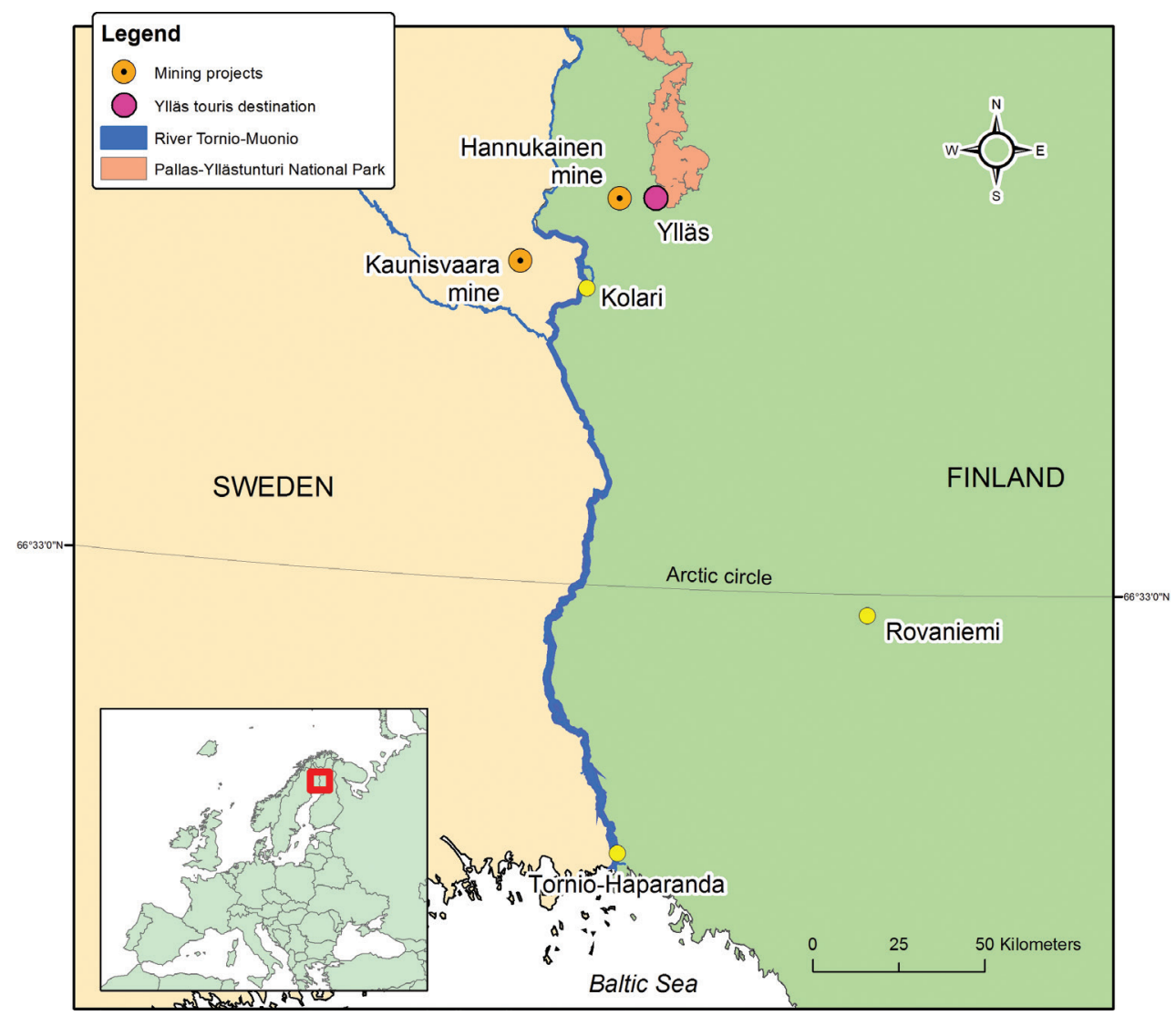

Figure 1. The Tornio-Muonio River between Finland and Sweden.

conditions. ${ }^{30}$ Plans also call for reopening the Kaunisvaara mine, which operated for two years and went bankrupt in $2014 .^{31}$ It, too, would pump its waste waters into the Tornio-Muonio River. Both mines could thus have significant non-local economic and environmental impacts over an area of hundreds of kilometers.

It is impossible to predict impacts of mining on tourism accurately. How customers ultimately behave is the outcome of many variables, including economics, politics and trends. However, studies show that there are true risks for tourism if mining is allowed. ${ }^{32}$ Risk analysis and best-worst case scenarios are essential to achieve sustainable and sound decision-making.

In 2016 a web survey on land-use issues was conducted by the municipality of Kolari and the Natural Resources Institute Finland. The data consisted of 254 responses from local residents, 378 responses from second-home owners and 273 from tourists. Altogether 1257 persons responded to the survey. The total number of respondents to the question "Do you approve of the Hannukainen mining project" was $585 . .^{33}$ In the survey people were asked whether or not there should be certain conditions set for the mine. The results presented in Figure 2 include only 


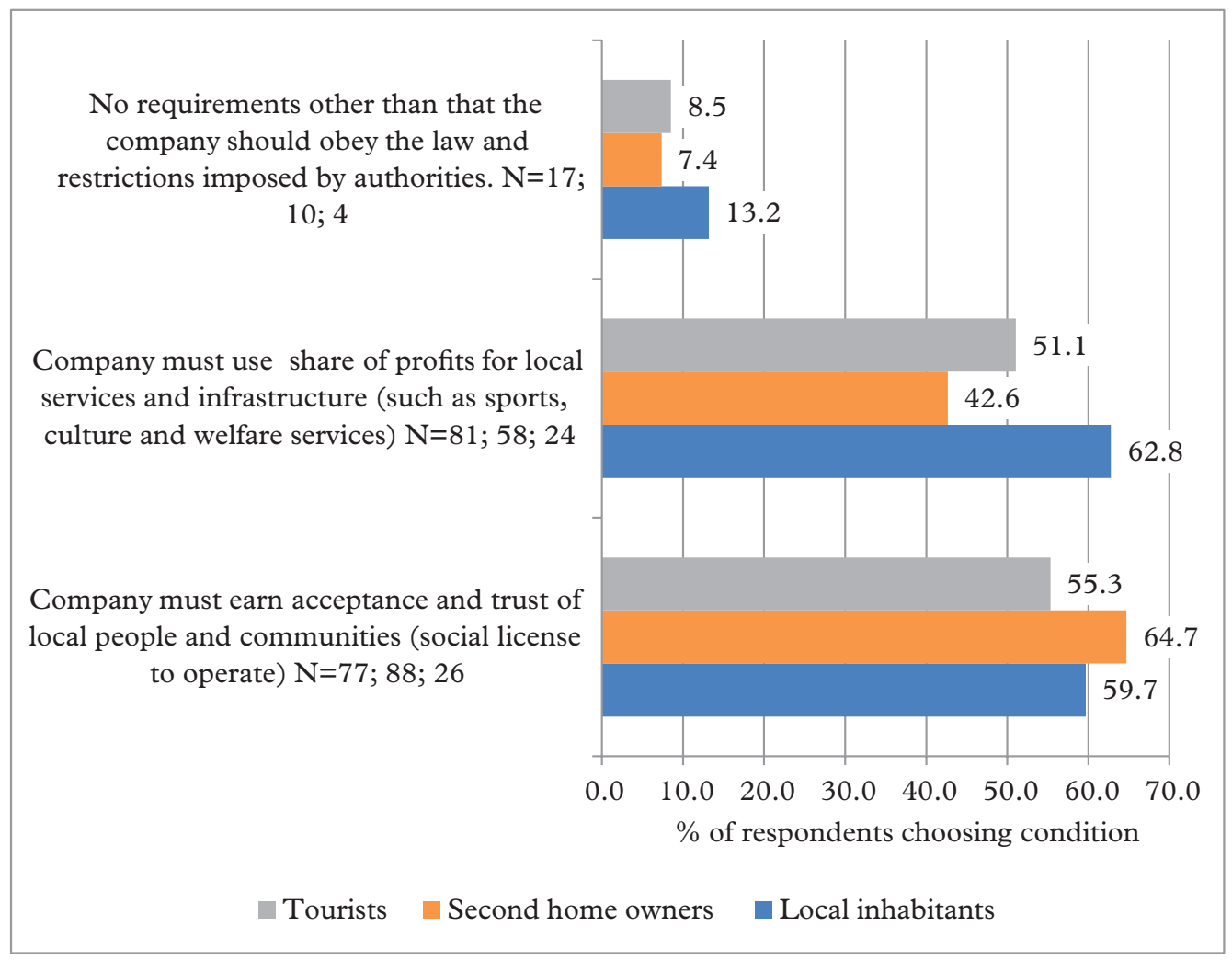

Figure 2. Conditions on the mining company.

respondents who would set certain conditions for acceptance of the project and the percentage of conditions chosen by stakeholder groups. Most respondents either rejected or accepted the mine outright.

According to the survey, local opinion on the Hannukainen project is extremely polarized. Eighty percent of residents living in villages near the mining site oppose the mine, while 67 percent of people in other villages support it. However, it is fair to say this is not just a case of NIMBY (not in my back yard). Those living near the site live mainly in the Ylläs tourist destinations, where most of the jobs, valuable real estate and business investments are located. In these locations the population has been growing rapidly (a 58 percent increase in the last fifteen years), whereas elsewhere in Kolari it is declining. ${ }^{34}$

The key conclusion to be drawn from the survey is that stakeholders, including local people, second-home owners and tourists, who could accept mining under certain conditions (see Figure 2) are of the view that the project will not become acceptable if it does no more than comply with the legally binding requirements of the relevant regulation. The results show that stakeholders have expectations that can be captured by the concept of 'social license to operate (SLO)'. 
According to Thomson and Boutilier, ${ }^{35}$ a social license to operate is a stakeholder community's perceptions of the acceptability of a company and its local operations. A stakeholder community is not just the geographical community, such as a village or municipality, but rather a network of stakeholders that the mining project can have an impact on and that can have impact on the project. Stakeholders can be local people, governmental and non-governmental organizations, companies, ethical investment funds and the like. The SLO is a social science concept which describes company-community relations and is used globally and in the Nordic countries for the extractive industries in particular. ${ }^{36}$ Today, mining companies globally seek an SLO to avoid conflicts, socially justify their operations and assure financers that projects entail no unbearable risks. An SLO is not granted by any authority, as it is not legal permit; it can be earned by social and public communication and through collaboration with local communities and stakeholder networks engaged in and affected by the project in question. ${ }^{37}$

While earning a social license to operate is of crucial importance in making a mining project successful, the project must also fulfil a range of legal requirements. Moreover, interaction during the legal processes may affect the social license. In the next section, we go on to assess the role of public regulation in resolving conflicts between mining and tourism industries.

\section{Role of Regulation in Resolving Conflicts between the Mining and Tourism Industries}

\subsection{Overview of the regulatory landscape}

In this section, we investigate how the exploitation of minerals in Finland is governed by regulation. We focus on the situation where mining and tourism are in an asymmetrically counterproductive relationship, for example, where a new or expanding mine is changing the landscape in a way that might have significant detrimental impacts on existing tourism businesses.

Exploitation of mineral resources is governed by many regulatory instruments which serve similar functions from country to country. In Finland, the key decisions in this regard include the environmental impact assessment (EIA, which often includes another assessment, known as the Natura assessment), ${ }^{38}$ land-use plans ${ }^{39}$ and mining permits, ${ }^{40}$ as well as environmental and water permits. ${ }^{41}$ Land-use plans and mining permits are particularly relevant for landscape changes. The environmental permit regulates emissions (pollution), but not physical changes to the landscape, and the Nature Conservation Act focuses on biodiversity. ${ }^{42}$

The environmental impact assessment procedure, which pertains to all types of environmental impacts (emissions, biodiversity, landscape etc.) is procedurally separate from the permitting processes. The EIA procedure precedes all permit and land-use planning processes, but it does not have legal effects. The assessment produces information but not changes in legal rights and obligations; however, this 
information must be taken into account in the permitting and land-use planning processes.

The multi-tier system of land-use planning takes the form of national land-use objectives, adopted by the Government; regional-level plans, adopted by the regional council; and two local-level plans (the master plan and town plan), adopted by the municipal council. National land-use objectives are not spatially explicit, whereas plans are. The most relevant land-use plan for mining is the master plan, discussed below. In this hierarchy, upper-level objectives or regional plans guide the preparation of local-level plans. While the three-tier hierarchy has a long history, recent years have seen a trend toward devolution within the hierarchy. This has, in essence, meant that state authorities have fewer possibilities than in the past to influence land-use planning decisions taken by municipalities.

While a project may only commence after all regulatory decisions have been made, the order in which these decisions are made may vary. The general rule is that a company requiring several permits may decide on the order in which it submits the permit applications, with regulators making their decisions independently unless the law provides otherwise.$^{43}$ However, the relationship between land-use planning and the mining permit is determined by the new Mining Act (621/2011); a land-use plan or other land-use decision must precede any decision on a permit. Furthermore, a mining permit may not be granted if mining would hinder the implementation of a land-use plan (master plan) which has legal effects. Even where no such plan exists, a mining permit may not be granted if a municipality opposes it on the basis of reasonable grounds related to land use. Outside land-use plan areas, the national mining authority may, in rare cases, decide to grant a mining permit regardless of opposition by the municipality if there are special reasons for doing so.

The new Mining Act adopted in 2011 serves as the legal basis for any mining permit application submitted thereafter. Applications for a mining patent, the term used in the old Mining Act, (503/1965) are subject to different rules. This is relevant for the present case, because the current mining company - Hannukainen Mining Ltd - bought mining rights from Northland Mines Ltd in 2015. Northland Resources submitted its mining patent application in December 2010, that is, under the old Mining Act. This being the case, the provisions of the new Mining Act apply to the new decision only in part, despite the fact that the new company significantly modified the application in 2015. In the analysis below, we focus on the new Mining Act and how it relates to other decisions. However, when necessary we point out how the old Mining Act differs from the new one so that the reader can understand how the decision-making process relevant for Hannukainen will proceed. The Hannukainen mine is the first new large-scale mining project to be decided on since the adoption of the new Mining Act. It is important to note that our principal aim is to assess the law as it stands now and discuss possible needs for improvement. 


\subsection{Role of land-use plans}

As noted above, a land-use planning decision must precede any decision on a mining permit. ${ }^{44}$ Mining activities should be based on a legally binding land-use plan or other uses of the land should be sufficiently clarified in co-operation with the local authority, the regional council and the Centre for Economic Development, Transport and the Environment. As a rule, this means full-scale planning in the form of a local master plan or other legally binding plan. Alternatively, a lighter planning procedure, called a 'decision on area requiring planning', can be used in cases where environmental impacts or the need to coordinate land uses is not significant. The use of the lighter process should be an exception. One could assume that the lighter alternative would concern only mining projects whose size is below the threshold set in the EIA Act, triggering the EIA procedure. However, there is no formal linkage between the two. Pölönen claims that the use of the lighter procedure for mining projects is ill-suited to the Finnish land-use planning system ${ }^{45}$ because the procedure will not guarantee a sufficiently comprehensive planning process. While a regional land-use plan could, in principle, satisfy the requirement of land-use planning prior to a decision on a mining permit, a municipality can override a regional plan with its own more detailed plan, discussed below.

Although a municipality is not obligated to start a full-scale planning process ${ }^{46}$ (perhaps because it does not support mining operations), some sort of a municipal decision is always required. A municipality must also express its opinion when it opposes a mining project. Where there is already an adequate legally binding landuse plan in effect, there is no need to make a new one, in which case a municipality may consider land-use issues resolved. However, as Finland is a large country, new mining projects are often planned in areas that are not covered by legally binding master plans. In sum, a municipality can always, if it so wishes, prevent a mine from being established in its jurisdiction. One could call this a right of veto, although this term is not used in the law.

The Building and Planning Act regulates planning in both procedural and substantive terms. The substantive requirements come from two directions: directly from the law and from the upper levels of the hierarchical planning system. The relevant considerations in preparing a local master plan, ${ }^{47}$ the most frequently used type of land-use plan for mining activities, are described in the Building and Planning Act using expressions such as 'the functionality, economy and ecological sustainability of the community structure; utilization of the existing community structure; and business conditions within the municipality. ${ }^{48}$ This kind of language draws the planner's attention to the issues which must be taken into consideration, but leaves it up to the planner to decide what to do in practice. The hierarchical planning system is based on the idea that upper-level plans or decisions guide lower-level planning. National land-use guidelines, which are not spatially explicit, are adopted by the Government and guide planning at the regional and local levels. However, the language used in the guidelines is broad. ${ }^{49}$ Their impact is similar to that of the 
substantive requirements explained above: they define the scope of issues to be considered in the planning processes but leave open the question of the actual outcome of this consideration.

The upper-level plan, namely the regional land-use plan, is more concrete than national land-use objectives. A local land-use plan must adhere to the land-use policy adopted in the regional plan, although a municipality need not follow it in all details. More concretely, even if an area has been set aside for mining in the regional plan, the municipality in question may decide to reserve the area for other purposes. This conclusion can be drawn from a recent decision of the Supreme Administrative Court ${ }^{50}$ concerning a wind farm in Muonio, Finnish Lapland. In this case, a specific area was reserved for a wind farm in the regional plan as well as in the proposed detailed plan, but the local municipal council rejected the plan. The council, a political body, came to a different conclusion than the civil servants who had prepared the proposal. The council concluded that the negative impacts of a wind farm on local tourism outweighed the farm's potential benefits in terms of energy production. ${ }^{51}$ The Supreme Administrative Court confirmed that the local council was entitled to make the decision it did.

While the steering mechanisms of local-level land-use planning are flexible, planning is still subject to legal oversight. Appeals against land-use plans may be filed with an administrative court not only by residents of the municipality and other affected parties, but also by the Centre of Economic Development, Transport and the Environment, the key state authority in land-use planning. For state authorities, the most important channel for influencing land-use planning today is pre-decision negotiations. ${ }^{52}$ However, authorities should not intervene where the principal consideration is expediency, the choice of which industries to favor being such a decision. Neither mining nor tourism can expect a state authority to try to influence a land-use plan significantly on the industry's behalf.

To counterbalance devolution, land-use planning processes have been made more transparent, interactive and evidence-based. There is less state control of local-level planning, but this means that citizens' opportunities to influence decision-making have been improved. Drawing from all relevant laws beginning with the Constitution, Eija Mäkinen ${ }^{53}$ has condensed the key ideas behind planning law into what she calls 'an ideal legal model for good planning'. This consists of three major statutory requirements: (1) transparent and interactive preparation in cooperation with stakeholders, (2) assessment of impacts and careful consideration of substantive requirements and (3) adequate weighing of various interests. To fulfil these requirements, planning needs to start with the preparation of a scheme for interaction procedures and impact assessment. This 'planning of the planning' is public and open to discussion. While the scale of evidence gathering is relative to the goals of planning, neglecting sufficient efforts to make impact assessments tends to backfire after a planning decision is made. Shortcomings in evidence gathering are the most frequently used arguments in appeals and are often successful. ${ }^{54}$ 
In sum, the substantive requirements of planning law relevant for promoting business activities - or giving a preference to one business over another - are general and leave a municipality with a large degree of discretion. This kind of decision-making is seen as furthering the 'consideration of expediency', which falls within the sphere of municipal self-government. The legal oversight system focuses on other kinds of issues, such as the tension between immediate economic benefits to the local community and impacts on the environment. ${ }^{55}$ Where there is tension between a new business activity and, say, Natura 2000 areas, the discretion of the planner is limited. Hence, appeals against planning decisions based solely on the argument that the land-use plan promotes the wrong businesses are unlikely to succeed.

The case of existing businesses is, however, somewhat different than that of prospective ones. A land-use plan should not cause unreasonable harm to landowners and the planner should take into consideration business conditions within the municipality ${ }^{56}$ Any plan neglecting these considerations is susceptible to legal criticism. The planner can, however, choose the manner in which these requirements are implemented. For example, while one can assume that any plan allowing mining close to a tourism area should contain a buffer zone, the size and form of a buffer zone may vary significantly.

A municipality's right of veto with regard to a mining permit and the trend of devolution in land-use planning have resulted in a situation where the resolution of conflicts between mining and tourism is almost solely up to the municipality. Legal oversight is relevant where the process is concerned, but less so as regards the substantive outcome of the decision-making. A transparent and interactive process and the requirement that any planning decision be based on evidence are the key safeguards of businesses that fear they may be negatively impacted by a particular land-use plan.

If an application for mining rights was submitted before July 2011, when the new Mining Act entered into force, the provisions of the new Mining Act will apply only in part. The key difference concerns the role of municipalities during the preparation of the decision on the mining patent. According to the new Act, a municipality can prevent the establishment of any mining project on grounds related to land use, as explained above. According to the old Act, a decision on land use need not be made before the mining authority makes its crucial decision on the patent. However, under the old law, where a detailed plan has been adopted before a patent is granted and the municipality objects to granting the patent on relevant grounds related to land use, the mining authority may not grant the patent without special reasons for doing so. This somewhat complicated rule gives the municipality a role in the process, but still leaves the final word to the mining authority. Despite the differences in the role of a municipality, the legal basis for setting permit conditions is the same under the old and new Mining Acts for all decisions made after July 2011. 


\subsection{Role of Mining Law}

\subsubsection{Basic Features of Mining Law}

There are three basic types of mineral ownership regimes world-wide, namely, the claim system, the concession system and the land ownership system. The salient idea of the claim system is that whoever discovers a mineral deposit can - subject to certain formalities - acquire the right to exploit it. The right is given to the party who first applies for it (first come, first served). In the concession system, the state has the power to decide whether to allow exploration for minerals and whom it will permit to do so. In the land ownership system, as the name suggests, mineral deposits are the property of the owner of the real estate where they are located. ${ }^{57}$

In a claim system, a mining company has the right to seek permission to exploit a mineral deposit - subject to the relevant formalities. Under the system, land owners are protected against economic losses, although a mining operation can be established without their approval. Hence, the position of mining companies is strongest under the claim system. The discretionary powers of mining authorities tend to be smaller in such a system than in a concession system. In the land ownership system, land owners have the final say as to whether a mining operation is allowed or not.

Finland has adopted the claim system for minerals - including all metal minerals defined in the Mining Act. Minerals not mentioned in the Act are owned by the landowner. For example, sand and gravel are regulated by the Land Extraction Act. Finnish mining law has been based on the claim system since the Mining Statute of 1857, when Finland was an autonomous Grand Duchy of Russia. ${ }^{58}$

In Finland, landowners cannot prevent the establishment of a mining project in their capacity as owners. However, they are allowed to receive compensation for damages caused by the mining company and are paid an excavation fee by the permit holder. For metal minerals, the fee is $50 €$ per hectare plus $0.015 \%$ of the calculated value of the minerals excavated and exploited in a year based on world market prices. For other minerals, the sum to be paid should be reasonable and, if not agreed, will be determined by the mining authority upon application..$^{59}$ Previously, mining companies also paid a claim fee to the state, but this fee was discontinued by the new Mining Act. The municipality where the mine is located is not entitled to any fee or other payment based on the Mining Act, although such a possibility was discussed when the law was being drafted. ${ }^{60}$

\subsubsection{Detrimental Impacts on Other Livelihoods}

According to section 1 of the current Mining Act, ${ }^{61}$ its objectives are to promote mining and organize the use of areas required for it, as well as exploration, in a socially, economically, and ecologically sustainable manner. In order to fulfill the purpose of the Act, public and private interests must be safeguarded, with particular attention to: (1) the preconditions for engaging in mining activity, (2) the legal status of landowners and private parties sustaining damage, (3) the impacts of activities on the environment and land use and (4) the economic use of natural resources. 


\section{fukka Similä E̋ Mikko fokinen}

The old Mining Act was heavily criticized for always giving priority to mining over other important public values. ${ }^{62}$ In response to this criticism, the objectives of the new Act were purposely defined broadly, suggesting that the role of the Mining Act in the overall regulatory landscape has changed significantly. This change appears as a move away from a traditional claim system, in which the role of the mining authority is limited to examining whether certain formalities are met and registering mineral rights. No doubt the registration of mineral rights is still an important function, because mining rights are an essential asset of mining companies and the basis for attracting financing. However, the legislative proposa ${ }^{63}$ for the Mining Act contains numerous references to public interests - the environment, the landscape, the Saami people, general living conditions, other livelihoods - which should also be taken into account. Whether the change in the objectives will result in any real change in practice depends on how permit conditions imposed under the new law differ from those set under the old one.

Next we explore the relevance of this reform from the perspective of nature-based tourism. Detrimental impacts of a mine on nature-based tourism may take many forms, such as noise, dust, light pollution and changes in the landscape. Hence, we ask to what extent these kinds of impacts are or could be regulated by a mining permit. The law requires that a mining permit must contain regulation to avoid, or at least limit, significant detrimental impacts on public and private interests (sections 18 and 52 read together). This must be read such that it includes the interests of tourism and other livelihoods.

However, due to broad-brush wording of the new Mining Act, adopted in 2011, legal confusion has arisen regarding what should be regulated in a mining permit and what in an environmental permit. The law does not make explicit the kinds of conditions that should be set out in an environmental permit and in a mining permit. Instead, in section 18, the Mining Act prescribes that mining activities must not cause significant harm to public or private interests or, in relation to the overall costs of the mining operations, reasonably avoidable infringement of public or private interests. Furthermore, the law requires that a mining permit should include necessary provisions for securing public and private interests, among others, to ensure that the activity does not result in any consequence prohibited by the Act, including those set out in section 18. On this basis, one could argue that mining permits should contain conditions applying to all types of detrimental impacts, even those covered by earlier environmental permit. This would lead to overlapping regulation.

While the wording of the Act is confusing, Pölönen and Halinen argue that systemic interpretation provides a solution. ${ }^{64}$ Systemic interpretation indicates that conditions on pollution should be imposed through an environmental permit, as the reform of the Mining Act in 2011 did not aim to narrow the scope of the Environmental Protection Act. The purpose of the reform was to improve and strengthen the protection of public and private interests. Hence, only conditions on detrimental impacts with other causes - physical changes, for example - should be included in 
a mining permit. However, as Pölönen and Halinen admit, the mining authority, which often makes its decision first, cannot know what kinds of permit conditions will be included in environmental permit. In its decision, the mining authority is obligated to cover all the considerations referred to in the Mining Act. In addition, the distinction between pollution and physical changes is not necessary clear. If a mine is located close to a tourism resort and it produces noise and dust as well as causing a loss of scenery, it might turn out to be difficult to decide whether the harm to public or private interests is due to pollution or physical change. Looked at from the perspective of the tourism industry, the question concerns the overall impact of mining on tourism. To avoid any loss of legal protection provided by law, the mining authority should impose permit conditions that minimize or prevent detrimental impacts on tourism, unless it is convinced that the matter will be regulated in the environmental permit.

The mining authority may reject a mining permit application if the proposed mining project is expected to: threaten public safety, have significant detrimental environmental impacts, or substantially lower the standard of living and hurt the local economy; if these danger or impacts cannot be remedied through permit regulations. ${ }^{65}$ In the legislative proposal for the Act, as well as in the legal literature, ${ }^{66}$ it is stressed that this provision is applicable only to large-scale mines and in exceptional circumstances. The legislative proposal mentions as examples cases where a mining project will destroy a valuable landscape or makes the area uninhabitable due to for example pollution. The model for this approach is clearly taken from the Water Act, which has a similar provision that has been applied only once.$^{67} \mathrm{It}$ is worth noting that this rule does not apply to permit applications submitted prior to the adoption of the new Mining Act, as is the case with the Hannukainen mine.

The key conclusion to be drawn here is that the Mining Act requires the mining authority to impose permit conditions which at the very least protect the tourism industry from detrimental impacts caused by physical (landscape) changes. Furthermore, we can conclude that the division of labor between the mining and environmental permits is not clear. Having said this, it is important to recall that only a limited number of decisions have been made under the new Mining Act and only one regarding a large-scale mine, namely, the case of Hannukainen. ${ }^{68}$ Furthermore, the decision concerning Hannukainen is not yet legally binding as an appeal against it has been made. Interpretation of the law is just beginning to emerge. As explained earlier, the new Mining Act applies only partially to the Hannukainen mine, as the permit application was initiated before the new Act was adopted. Nevertheless, sections 18 and 52 apply to all mining permit decisions under the new Mining Act, including those pertaining to Hannukainen. However, the dearth of decisions on large-scale mines means that we need to be cautious in drawing conclusions from the current permitting practice.

Although the mining authority did not impose any permit conditions to protect tourism in the Hannukainen case, it did not exclude the possibility of imposing such 
permit conditions in other cases. Many stakeholders drew attention to the lack of an appropriate assessment of the mine's impact on tourism and pointed out that changes in the landscape cause detrimental impacts on nature-based tourism. The authority considered the claims concerning impact assessment too general, and ignored them. However, it noted that if mining should cause clearly observable detrimental impacts on tourism, it would be possible to impose new permit conditions later to mitigate or even fully prevent such impacts. In our opinion it is the task of the applicant to provide an appropriate impact assessment and the responsibility of the permit authority to ensure that such an impact assessment is made.

The vague wording that the permit authority uses in order to fulfil the requirements in sections 18 and 52 open to criticism. After the adoption of the new Mining Act, the authority has imposed in most, if not all, cases a standard permit condition in which it repeats the following broad-brush wording of the law: "Mining shall not give rise to significant harm to the public or the private interest nor infringement of public or private interests." No one knows what this formulation means in concrete terms and yet permit holders may unwittingly violate its terms. Using this kind of regulatory wording runs counter to the entire idea of permitting. The function of permitting is to turn general, non-specific norms of legislation into case-specific conditions that concretely define what the permit holder should or should not do in a particular case. Excessively broad wording makes enforcement of permit conditions extremely challenging if not impossible. The Mining Act requires systematic monitoring, ${ }^{69}$ although it leaves the details of this up to the mining authority. If a permit authority does not know in specific terms what it expects the permit holder to do, how can the recipient company know? Open-ended formulations of legal requirements in a permit are unlikely to have any impact whatsoever on public or private interests.

From a legal point of view, the key conclusion is that the mining authority should determine whether a mine may harm tourism or other livelihoods and, if so, impose permit conditions that mitigate or prevent these impacts. While rejection of a permit application on the basis of detrimental impacts on other livelihoods is apparently possible in exceptional situations, imposing permit conditions could be utilized more often.

\section{Discussion}

The impact a new mine has on tourism will vary from case to case, depending on: the location of the mining facilities, the physical size of the project, the mining processes used, logistics, as well as the image of the mining company and its end product. Tourism is a business that is dependent on an image that sells. If the image of a tourism destination is tainted because of its proximity to a mine, the entire business is in danger. Every mining case is unique and parallels drawn between different mines easily prove invalid. ${ }^{70}$ 
While tourism and the mining industry may benefit from each other, the relationship between a mine and tourism is often asymmetrically counterproductive; a new mine will in most cases significantly reduce the attractiveness of a tourism destination. If this tension is left to be resolved through negotiations between the two industries, in the spirit of the so-called Coase theorem, ${ }^{71}$ the bargaining power of the tourism industry is weak. The existence of an asymmetrical counterproductive relationship justifies the need for regulation.

The challenge is that long-term impacts are not easy to anticipate nor is it easy to produce evidence of these impacts. Both underestimating and exaggerating the impacts of mining may be a problem. Mining, in particular, is an activity that is likely to trigger public protests because of misunderstanding its impacts. This can create a social phenomenon called 'moral panic', which involves creating a sense of insecurity among a certain group of people by exaggerating facts that are perceived as problematic. ${ }^{72}$

In the Finnish legal system, the key regulatory instruments capable of addressing an asymmetrical counterproductive relationship between mining and tourism are land-use plans and mining permits. Environmental permits, while extremely relevant for emissions control, are not designed to address physical changes in the landscape. Land-use planning offers a means for reconciling conflicts between mining and tourism through the allocation of land to different uses across an area in a way that balances the needs of the two industries. Whether buffer zones and other planning choices will effectively mitigate detrimental landscape impacts on neighboring tourism activities depends on the particular circumstances of the case. It may be that mining will detrimentally affect neighboring tourism businesses regardless of what the planner does. In such instances, a fundamental choice has to be made as to which industry is given preference. According to representatives from the tourism industry, this is the case with the Hannukainen mine. ${ }^{73}$ They firmly believe that a new mine would have a significant negative economic impact on their nature-based business.

A planner needs to follow procedural rules, gather relevant information and give reasonable grounds for decisions made, but ultimately these decisions are of a political nature. The ideal model for implementing land-use planning aims to ensure that decisions are well-grounded, but this model may fail due to insufficient information, difficulties in assessing the significance of the information available and regulatory capture. ${ }^{74}$

It is doubtful whether a municipality is the best public body to decide on large-scale projects with extensive impacts beyond municipal boundaries. A small municipality such as Kolari, which has a population of fewer than 4,000 people, may lack the resources and expertise necessary for the careful impact assessment and transparent and interactive collaboration among all relevant stakeholders that the ideal decision-making model requires. The problem is, however, that it is not easy to point to any other public body that would be better suited to this task. Furthermore, 


\section{Fukka Similä \& Mikko fokinen}

democratic control through local elections serves as a safeguard that decisions are made for the benefit of the local population as a whole.

Recently the town of Kuusamo in northeast Finland determined that a proposed mine that would be situated close to a tourist destination would cause excessive risks to tourism. The municipality adopted a strategic land-use plan that strictly limits the area where mining is allowed. This is an example of how a municipality may give priority to tourism over mining in an asymmetrical conflict situation. ${ }^{75}$ Structurally the Kuusamo decision is similar to that of the municipality of Muonio regarding the wind farm noted above. While the Kuusamo case shows how land-use planning can be used to restrict areas available for mining, it also stresses the crucial role of the municipality in this process. The municipality of Kuusamo decided to favor tourism; another municipality might resolve the tension between a mine and a tourism destination differently. Ultimately, the decision is political in nature, and the possibility that different municipalities may reach different conclusions is unproblematic as such. In fact, diversity of values, avoidance of interest capture and opportunities for experimentation are all arguments commonly used in promoting the decentralization of power. ${ }^{76}$

Not only land-use planning but also mining permits could be used for the purpose of reconciling conflicts between different industries, as the objective of the Mining Act indicates. ${ }^{77}$ Unlike land-use planning, permit conditions are addressed to the permit holder only. Permit conditions could, for example, aim to prevent or minimize detrimental impacts caused by landscape changes (physical changes) on living conditions, local amenities or other livelihoods, like tourism. ${ }^{78}$ While it is clear that the Mining Act not only allows but requires the mining authority to impose permit conditions to avoid harm to public and private interests, no effective permit conditions have been developed in the permitting practice to date. The mining authority has merely reproduced the general wording of the legislation in its decisions. This practice runs counter to the idea of permitting. Permitting should concretize what the general rules and requirements of legislation mean in an individual case. The use of permit conditions such as those seen thus far renders ineffective the substantive requirements of the Mining Act, which seeks to protect public and private interests. This means that the key objective of the Mining Act, namely organization of "the use of areas required for (mining), and exploration, in a socially, economically, and ecologically sustainable manner", is not being met.

The Mining Act has a safeguard mechanism for extreme cases, which is designed to be used in rare situations. ${ }^{79}$ The mining authority, the Finnish Safety and Chemicals Agency, should refuse to grant a mining permit if the mining operation in question will cause large-scale negative impacts on other livelihoods or the environment. However, the Agency is a highly specialized state authority that focuses on technical issues with only limited staff and expertise available.$^{80}$ The responsibility of making a decision that is mainly based on economic policy and coordination of land uses is ill-suited to such a body. This role is particularly ill-suited because it means that the 
mining authority might have to overrule a decision made by the municipal council, a political body. The situation becomes even more curious when one takes into account that the procedural requirements of the planning process are more demanding than those for a mining permit.

While the mining authority, the Finnish Safety and Chemicals Agency, is not the right body to assess whether mining will cause large-scale negative impacts on other livelihoods or the environment, the idea of having a legal safeguard is worth keeping in the Finnish legal system. However, the choice of which public body should be given this jurisdiction is not obvious, because the safeguard mechanism includes components that fall under the remit of different authorities: danger to public safety, highly significant detrimental environmental impacts, and substantial impacts on living conditions and the local economy (i.e. other livelihoods). One possibility would be to keep the substantive content of section 48(2) in the legal system, but give decision-making authority to other bodies. The body granting environmental permits could decide whether mining would endanger public safety or result in highly significant detrimental environmental impacts. The municipality could decide whether mining would cause unacceptable detrimental impacts on living conditions and other businesses and industries. Oversight of municipal decision-making would be the function of the courts.

\section{Conclusions}

At present the Finnish Safety and Chemicals Agency seemingly does not use its authority to fulfil the key objective of the Mining Act, namely, organization of the use of areas required for mining in a socially, economically, and ecologically sustainable manner. The practice of this public body has been to reproduce in mining permits the general and abstract requirements of the legislation without giving concrete case-specific content to the wording of the law; this renders permitting ineffective. The mining authority should, in our opinion, improve the way in which it formulates permit conditions to give them concrete content.

Furthermore, the Finnish Safety and Chemicals Agency is not, in our opinion, the right public body to decide whether a mining operation might cause detrimental social and environmental impacts on such a scale that the proposed mining should be prohibited. The safeguard mechanism as such is valuable, but the authority to invoke it should be transferred to other public bodies, such as the environmental permit authority and the planning authority (municipal council).

The interests of different land uses and livelihoods should be reconciled as part of the land-use planning process. Local authorities and political decision-makers in Kolari face a real challenge in land-use planning, because legal representatives from the municipal council will have to decide if it is worth accepting a moderate risk. In the case of the Hannukainen mine their responsibility is weighty because the mine may seriously impact the quality of the environment and livelihoods in 
two countries - Finland and Sweden - along the Tornio-Muonio River and the Bothnian Bay.

A small municipality with limited staff and expertise tasked with deciding which industry should be given preference is not necessarily an optimal situation. However, it is difficult to point to a public body or mechanism that would be better. The legal oversight of the planning decision ensures that procedural rules are followed, relevant information gathered and reasonable grounds for decisions given, but it leaves open the question of which industry should be given preference in a given locality. Hence, we conclude that there is no need to change the role of municipalities or land-use planning law in addition to what we have concluded above. This conclusion pertains only to the general legal framework; how successfully an individual municipality manages to use its powers is another question.

\section{ACKNOWLEDGEMENTS}

The research is funded from the Academy of Finland project (nr 283116) 'Governing adaptive change towards sustainable economy in the Arctic'. We are grateful for the constructive comments of the reviewer.

\section{NOTES}

1. Corresponding author, Jukka Similä, University of Lapland, P. O. Box 122, 96101, Rovaniemi, Finland; Jukka.Simila@ulapland.fi.

2. Sharman Haley, Matthew Klick, Nick Szymoniak \& Andrew Crow, "Observing trends and assessing data for Arctic mining”, Polar Geography 34 (2011):1-2, 37-61. DOI:10.1080/ 1088937X.2011.584449; Timo Koivurova et al., "Legal Protection of Sami Traditional Livelihoods from the Adverse Impacts of Mining: A Comparison of the Level of Protection Enjoyed by Sami in Their Four Home States" Arctic Review on Law and Politics 6 (2015): 11-51; Taylor Jackson and Kenneth P. Green, Fraser Institute Annual Survey of Mining Companies 2016 (Frazer Institute 2017): 74.

3. Gavin Bridge, "Contested Terrain: Mining and the Environment", Annual Review of Environment and Resources 29 (2004): 205-259. DOI: 10.1146/annurev.energy.28.011503.163434.

4. Hens Runhaar and Kim van Nieuwaal, "Understanding the use of science in decisionmaking on cockle fisheries and gas mining in the Dutch Wadden Sea: Putting the sciencepolicy interface in a wider perspective". Environmental science E policy 13 (2010:) 239-248. DOI:10.1016/j.envsci.2010.03.001

5. There have also been major industrial conflicts elsewhere in the world, for example, between farmers and mining and between large-scale and small-scale miners. Gavin Hilson, "An overview of land use conflicts in mining communities", Land Use Policy 19 (2002): 65-73.

6. Lars Bäckström, Svensk gruvrätt, En rättsvetenskaplig studie rörande förutsättningarna för utvinning av mineral (Luleå tekniska universitet 2015). Bent Ole Gram Mortensen, "Arctic Mining: The Case of Greenland", The Yearbook of Polar Law 7 (2015) 102-127; Kai Kokko, Arild Buanes, Timo Koivurova, Vladimir Masloboev, Maria Pettersson, "Sustainable mining, local communities and environmental regulation", Barents Studies: Peoples, Economies and Politics 2 (2015) 50-81.

7. Ole Kristian Fauchald, "Regulating Environmental Impacts of Mining in Norway" Nordic Environmental Law fournal 1 (2014). Maria Pettersson, Anniina Oksanen, Tatiana 
Mingaleva,Victor Petrov, Vladimir Masloboev "License to Mine: A Comparison of the Scope of the Environmental Assessment in Sweden, Finland and Russia", Natural Resources, 6 (2015) 237-255. Kristina Söderholm, Payrik Söderholm, Heidi Helenius, Maria Pettersson, Roine Viklund, Vlamiir Masloboev, Tatiana Mingaleva and Viktor Petrov, "Environmental regulation and competitiveness in the mining industry: Permitting processes with special focus on Finland, Sweden and Russia", Resources Policy 43 (2015) 130-142.

8. ibid. note 1 Koivurova et al. 2015; Timo Koivurova and Anna Petrétei, "Enacting a New Mining Act in Finland - How Were Sami Rights and Interests Taken into Account?" Nordic fournal of Environmental Law (2014): 119-133.; Jan Darpö, "Karin och Susannes glädje, Lars-Anders sorg? Om uppdelade tillståndsprövningar på miljöområdet och respekten för samernas renskötselrätt” Nordic Journal of Environmental Law (2016): 71-87. Alexis Monique Lerner et al. "Mitigating the Risks of Resource Extraction for Industrial Actors and Northern Indigenous Peoples" Arctic Review of Law and Policy 8 (2017): 23-51, DOI: https://doi.org/10.23865/arctic.v8.659.

9. Ismo Pölönen, "Kaivokset kaavoissa. Kunnan harkintavalta yleiskaavoituksessa kaivostoiminnan ohjauksen näkökulmasta" (Mines in the Land Use Plans - Discretion of the Municipalities in Directing the Mining Activities Through Master Planning) Oikeus (2016): 70-91.

10. Brett M., Frischmann, Environmental infrastructure. Ecology Law Quarterly 35:2 (2008): 151; Frischmann, Brett M., Infrastructure. The Social Value of Shared Resources (Oxford University Press 2012), 154-156.

11. Peter Fredman and Liisa Tyrväinen, "Frontiers in Nature-Based Tourism" Scandinavian fournal of Hospitality and Tourism 10 (2010):177-189, DOI:10.1080/15022250.2010.502365.

12. Susanna Heldt Cassel \& Albina Pashkevich, "Heritage Tourism and Inherited Institutional Structures: The Case of Falun Great Copper Mountain", Scandinavian fournal of Hospitality and Tourism 11 (2011):1, 54-75. DOI: 10.1080/15022250.2011.540795

13. Arto Alajärvi, Asko Suikkanen, Leena Viinamäki, Leena and Martti Ainonen, " Kaivosyhdyskunnan purkautuminen: tutkimus Kolarin Rautuvaaran kaivoksen sulkemisesta ja yhdyskunnan uudelleen rakenteistumisesta". Lapin korkeakoulun yhteiskuntatieteellisiä julkaisuja B. Tutkimusraportteja ja selvityksiä: 10 (1990). 130 p.

14. Kauko Puustinen, "Suomen kaivosteollisuus ja mineraalisten raaka-aineiden tuotanto vuosina 1530-2001, historiallinen katsaus erityisesti tuotantolukujen valossa". (Finnish mining industry and mineral production during the years 1530-2001). Geologian tutkimuskeskus, arkistoraportti, M 10.1/2003/3. 578 p. (2003). Accessed May 15, 2018. http://weppi.gtk.fi/ aineistot/kaivosteollisuus/; Marja Liisa Räisänen, Amélie Beucher, Anna Tornivaara and Päivi Kauppila, "Suljettujen ja hylättyjen metallikaivosalueiden nykytila ja arvio jätealueiden ympäristöriskipotentiaalista”. Geologian tutkimuskeskus, Arkistoraportti 46/2015. (2015). 129 p. Accessed May 15, 2018. http://tupa.gtk.fi/raportti/arkisto/46_2015.pdf.

15. Tukes, "Yhteenveto Hannukaisen kaivospiirihakemuksesta". KaivNro K8126. (2016). 26 p. Accessed May 15, 2018. http://www.tukes.fi/Tiedostot/kaivokset/Kuulutukset/hannukainen $\% 20$ kuuleminen_netti.pdf

16. http://www.hannukainenmining.fi/ajankohtaista/galleria.html Hannukaisen kaivoksen tulevaisuuden suunta ja visio -video. [Cited February 24, 2017]; Tukes 2016.

17. Kari Heiskanen, 'Lausunto Ympäristölaki Oy:lle Hannukainen Mining Oy:n ympäristö- ja vesilain mukaisesta lupahakemuksesta Dnro PSAVI/3224/2015. (2017)". in Muistutus/ mielipide koskien Hannukainen Mining Oy:n Hannukaisen ja Rautuvaaran kaivoshankkeen ympäristö- ja vesitalouslupahakemusta Kolarissa. Muonion paliskunta, Destination Lapland Oy, Jounin Kauppa Oy, Ylläksen Ystavät ry, Äkaslompolon kyläyhdistys, Ylläksen Matkailuyhdistys ry, Lapland Hotels Oy ja Ylläksen Matkailu Oy. Appendix 1. (2017). 55 p.; Elinkeino-, liikenne- ja ympäristökeskus, "Lausunto 14.9.2017 Kalatalouspalvelut/PohjoisSuomi". LAPELY/1841/2017. (2017). 3 p. 


\section{Fukka Similä \& Mikko fokinen}

18. Tukes, "Yhteenveto Hannukaisen kaivospiirihakemuksesta". KaivNro K8126. (2016). 26 p. Accessed May 15, 2018. http://www.tukes.fi/Tiedostot/kaivokset/Kuulutukset/hannukainen\%20kuuleminen_netti.pdf; Hannukaisen kaivoshanke - Kaivannaisjätteen jätehuoltosuunnitelma. (2018) Päivitetty 16.4.2018. Pöyry Finland Oy. Accessed May 24, 2018. https:// tietopalvelu.ahtp.fi/Lupa/Lisatiedot.aspx?Asia_ID=1252637

19. Puustinen, "Suomen kaivosteollisuus ja mineraalisten raaka-aineiden tuotanto vuosina 15302001, historiallinen katsaus erityisesti tuotantolukujen valossa".; Räisänen et al., "Suljettujen ja hylättyjen metallikaivosalueiden nykytila ja arvio jätealueiden ympäristöriskipotentiaalista".

20. Statistics Finland 2017.

21. Metsähallitus 2018. Accessed May 15, 2018. http://www.luontoon.fi/pallas-yllastunturi

22. Lapin Liitto, "Lapland's tourism strategy 2011-2014". Rovaniemi: Lapin liitto. (2011). 74p. Accessed May 15, 2018. http://www.lappi.fi/lapinliitto/fi/lapin_kehittaminen/strategiat/ lapin_matkailustrategia.

23. Hannukaisen kaivoshanke (2013).Ympäristövaikutusten arviointiselostus. Northland Mines Oy. Accessed May 15, 2018. http://www.ymparisto.fi/fi-FI/Asiointi_luvat_ja_ymparistovaikutusten_arviointi/Ymparistovaikutusten_arviointi/YVAhankkeet/Hannukaisen_rautakaivoshanke_Kolari/Hannukaisen_rautakaivoshanke_ymparistova(24263)

24. Marja Hannula, "Kaivoshanke nostatti ison vastustuksen" (Mining project caused strong resistance), Helsingin Sanomat, September 18, 2017. A 26.; Milla Sallinen, "Montaa mieltä saman veden äärellä" (Different opinions at the same river), Lapin Kansa, October 7, 2017. P. 8.

25. Mikko Jokinen and Liisa Tyrväinen, "Ylläksen ja Levin matkailijoiden suhtautuminen Hannukaisen kaivoshankkeeseen ja Kittilän kaivokseen". (Opinions of Ylläs and Levi tourists on the Hannukainen and Kittilä mining projects). Hannukaisen kaivoshanke - ympäristövaikutusten arviointiselostus. Northland Mines Oy. (2013). 32 p.; LiisaTyrväinen, Marja Uusitalo, Harri Silvennoinen and Eija Hasu," Towards sustainable growth in nature-based tourism destinations: Clients' views of land use options in Finnish Lapland". Landscape and Urban Planning, Vol 122 (2014): 1-15; Sanna Hast and Mikko Jokinen, "Elinkeinojen yhteensovittaminen - Tarkastelussa kaivostoiminta, poronhoito ja luontomatkailu", (Reconciliation of mining, reindeer herding and nature-based tourism). Kaivos suomalaisessa yhteiskunnassa, eds, Tuija Mononen and Leena Suopajärvi (Rovaniemi: Lapin yliopistokustannus 2016): $86-110$

26. Ibid. Hast and Jokinen 2016; ibid. Jokinen and Tyrväinen 2013.

27. Ibid note 25; Jokinen and Tyrväinen 2013.

28. Mikko Jokinen, "Hannukaisen kaivos ja matkailu" (Hannukainen mine and tourism), Matkailun kehitysnäkymät - mitkä ovat seuraavat askeleet -seminaari. 2014. Accessed May 15, 2018. http://www.metla.fi/hanke/7451/pdf/Matkailun-kehitysnakymat_seminaari_ 17.2.2014.pdf.

29. Kukka Pakarinen, "Kaivoshankkeesta koituvat ekotoksikologiset riskit", in Muistutus/mielipide koskien Hannukainen Mining Oy:n Hannukaisen ja Rautuvaaran kaivoshankkeen ympäristöja vesitalouslupahakemusta Kolarissa. Muonion paliskunta, Destination Lapland Oy, Jounin Kauppa Oy, Ylläksen Ystävät ry, Äkäslompolon kyläyhdistys, Ylläksen Matkailuyhdistys ry, Lapland Hotels Oy ja Ylläksen Matkailu Oy. Appendix 2. (2017).

30. Ibid.; Kari Heiskanen, 'Lausunto Ympäristölaki Oy:lle Hannukainen Mining Oy:n ympäristö- ja vesilain mukaisesta lupahakemuksesta Dnro PSAVI/3224/2015. (2017)". in Muistutus/mielipide koskien Hannukainen Mining Oy:n Hannukaisen ja Rautuvaaran kaivoshankkeen ympäristö- ja vesitalouslupahakemusta Kolarissa. Muonion paliskunta, Destination Lapland Oy, Jounin Kauppa Oy, Ylläksen Ystavät ry, Äkaslompolon kyläyhdistys, Ylläksen Matkailuyhdistys ry, Lapland Hotels Oy ja Ylläksen Matkailu Oy. Appendix 1. (2017). 55 p.; Elinkeino-, liikenne- ja ympäristökeskus, "Lausunto 14.9.2017 Kalatalouspalvelut/Pohjois-Suomi”. LAPELY/1841/2017. (2017). 3 p. 
31. "New jobs for Pajala when Kaunis Iron opens the mine". Kaunis Iron (2018) https://www. kaunisiron.se/aktuellt/; "Swedish iron ore miner Northland Resources goes bankrupt". Mining.com (2014). http://www.mining.com/swedish-iron-ore-miner-northland-resourcesgoes-bankrupt-73699/. Accessed May 15, 2018.

32. Ibid. note 25 Hast and Jokinen 2016; ibid. note 25 Jokinen and Tyrväinen 2013.

33. The municipality of Kolari and Natural Resources Institute Finland have the original survey data.

34. Statistics Finland 2018.

35. Ian Thomson and Robert G. Boutilier, "Modelling and Measuring the Social License to Operate - Fruits of a Dialogue Between Theory and Practic". (2011) 10 p. Accessed October 9, 2017. https://socialicense.com/publications.html.

36. Timo Koivurova, Arild Buanes, Larissa Riabova, Vladimir Didyk, Thomas Ejdemo, Gregory Poelzer, Päivi Taavo \& Pamela Lesser, "Social license to operate: a relevant term in Northern European mining?", Polar Geography, 38 (2015): 194-227.

37. Ibid. and Jason Prno and D. Scott Slocombe. "Exploring the origins of 'social license to operate' in the mining sector: Perspectives from governance and sustainability theories". Resources Policy. Volume 37 (2012): 3. Pp. 346-357. Accessed October 9, 2017. http://doi. org/10.1016/j.resourpol.2012.04.002.

38. Act on Environmental Impact Assessment Procedure 252/2017. Natura assessment is based on the requirements of the Article 6 of the Habitats Directive (Council Directive 92/43/EEC of 21 May 1992 on the conservation of natural habitats and of wild fauna and flora) and its implementation legislation The Nature Conservation Act (1096/1996), particularly Sect. 65.

39. Land Use and Building Act (132/1999).

40. The Mining Act (621/2011).

41. The environmental permit is governed by the Environmental Protection Act (527/2014) and the water permit by the Water Act (587/2011). Where an activity needs both, environmental and water permits are handled together procedurally. For mining, this is practically always the case.

42. Supreme Administrative Court decision, KHO 2005:27; Matias Wallgren, "KHO:2005: 27Ympäristönsuojelulain suhde maiseman- ja luonnonsuojeluun" Edilex. (24.4.2006) Accessed May 15, 2018. http://www.edilex.fi/lakikirjasto/3199.pdf.

43. Niko Soininen, "Luonnonsuojelullisen poikkeusluvan ja hankeluvan välisestä edellytyssuhteesta ympäristöoikeudessa" (Linkage and Concurrence of Environmental Permits) Ympäristöjuridiikka (2015): 10.

44. Section 47 of the Mining Act (621/2011).

45. Ibid. note 9,80 .

46. Ibid. note $9,73-75$.

47. Section 39 of the Land Use and Building Act (132/1999).

48. The Land Use and Building Act (132/1999) Sect. 39.

49. For example, Section 4.2. states that "Land use should support a balanced development of the regional structure and strengthen the competitiveness of business and industry, including internationally, by taking, as well as possible, advantage of existing structures and promoting an improvement in the quality of the living environment and a sustainable utilisation of the natural resources. The development of the regional structure and the land use should primarily be based on the individual strengths and location factors of the areas."

50. Supreme Administrative Court decision, KHO 2015:95.

51. Liisa Tyrväinen et al., "Selvitys matkailijoiden suhtautumisesta Mielmukkavaaran tuulipuistohankkeeseen. (Report on tourist opinions on Mielmukkavaara wind farm project). Metla Working Papers 237, 2012. Accessed May 24, 2018. http://www.metla.fi/julkaisut/workingpapers/2012/mwp237.htm. 


\section{Fukka Similä \& Mikko fokinen}

52. Eija Mäkinen, ”Tarvitaanko kuntien kaavoituksen viranomaisvalvontaa?” (Is control over municipal land use planning needed?) Ympäristöjuridiikka 2007: 24-48, 31

53. Ibid. 24-26.

54. Susanna Wähä, "Hallinto-oikeuksien asemakaavaratkaisujen kumoutumisperusteet 20012005" (Grounds for overturning detailed land-use plans in administrative courts 20012005) (Ympäristöministeriön raportteja 18/2006): 20-21; Kari Kuusiniemi, "Selvitys oikaisukehotusmenettelyn kehittämisestä" (Report on the development of rectification procedure) 165 (Ympäristöministeriön moniste 2006): 14; Susanna Wähä, "Maankäyttö- ja rakennuslain soveltaminen hallintotuomioistuimissa 2001-2003. (Application of the Land Use and Building Act in administrative courts 2001-2003) (Suomen ympäristö 2004): $17-26$.

55. Ibid. note 52, 25-46.

56. Section 39 of the Land Use and Building Act.

57. Eva Liedholm Johnson, Mineral Rights - Legal Systems Governing Exploration and Exploitation (Stockholm: Royal Institute of Technology 2010). Eva Liedholm Johnson and Magnus Ericsson, "State ownership and control of minerals and mines in Sweden and Finland" Mineral Economics 28 (2015): 23-36. DOI 10.1007/s13563-015-0063-2

58. Ibid. Eva Liedholm Johnson and Magnus Ericsson 2015.

59. The Mining Act (621/2011) ss. 99-102.

60. Parliamentary Economic Committee Report (Talousvaliokunnnan mietintö) 49/2010.

61. The new Mining Act (621/2011) entered into force July 1st, 2011 and it replaced the previous one (503/1965).

62. Suomen Luonnonsuojeluliitto 2010. Lausunto ympäristövaliokunnalle kaivoslaista. (The Finnish Association for Nature Conservation - Statement on the new Mining Act). [http:// www.sll.fi/ajankohtaista/liitto/2010/sll-ymv-kaila-230310]. Cited June 7, 2016.

63. Legislative proposal HE 273/2009 vp. 84.

64. Ismo Pölönen and Arja Halinen, "Harmonisointia ilman koherenssia - kaivoslain toimivuus kaivos- ja ympäristölupamenettelyjen suhteiden näkökulmasta" (Harmonization without coherence - the functionality of the Mining Act from the perspective of mining and environmental permitting), Edilex lakikirjasto, 31 (2017): 1-21. Accessed May 24, 2018. https:// www.edilex.fi/artikkelit/17855.pdf

65. The Mining Act (621/2011), s. 48 .

66. The legislative proposal for the Mining Act (HE 273/2009 vp), page 105; Ismo Pölönen,"Ympäristönäkökohtien ja paikallisten toimijoiden asema kaivoslain mukaisessa lupaharkinnassa", (Role of environmental aspects and local stakeholders in permit discretion, Lakimies (2013): 414-435, 425-426

67. Supreme Administrative Court Decision 2002:86 concerning a large artificial lake whose impact area would have been particularly extensive.

68. Decision K8126 of the Mining Authority TUKES, issued September 18th, 2017.

69. The Mining Act (621/20111) ss. 152-161.

70. ibid. note 25 , Hast and Jokinen.

71. Ronald Coase, "The Problem of Social Cost", fournal of Law and Economics 3 (1960):1-44.

72. Jarosław Badera and Paweł Kocoń, "Moral panic related to mineral development projects Examples from Poland" Resources Policy 45 (2015): 29-36. DOI: 10.1016/j.resourpol. 2015.03.009

73. Marja Hannula, ” Kaivoshanke Ylläksellä: jätevedet lohijokeen, rinteiltä näkymä louhokseen - Jounin kaupan kauppias mukana vastarintaliikkeessä" (Mining project in Ylläs: waste waters piped into a salmon river, open pit visible from the ski slopes - owner of Jounin kauppa joins the protest), Helsingin Sanomat, September 18, 2017. A 26. Accessed May 24, 2018. https://www.hs.fi/talous/art-2000005372069.html 
74. Regulatory capture refers to a government failure that occurs when a regulatory agency created to act in the public interest instead advances the commercial or political agenda of special interest groups that dominate the industry or sector it is charged with regulating. There is a large literature on this topic, see for example Jean-Jacques Laffont and Jean Tirole, "The Politics of Government Decision-Making: A Theory of Regulatory Capture," The Quarterly fournal of Economics 106 (1991): 1089-1127. https://doi.org/10.2307/2937958

75. Ibid, note 9.

76. Robert W. Hahn, Anne Layne-Farrar and Peter Passell, "Federalism and Regulation: An Overview". Regulation, Vol. 26, No. 4, pp. 46-50, Winter 2003-2004; AEI-Brookings Joint CenterWorking Paper No. 03-14. Accessed May 24, 2018. https://ssrn.com/abstract $=506062$

77. "The objective of this Act is to promote mining and organise the use of areas required for it, and exploration, in a socially, economically, and ecologically sustainable manner". Section 1 of the Mining Act.

78. Ismo Pölönen and Arja Halinen, "Harmonisointia ilman koherenssia - kaivoslain toimivuus kaivos- ja ympäristölupamenettelyjen suhteiden näkökulmasta" (Harmonization without coherence - the functionality of the Mining Act from the perspective of mining and environmental permitting), Edilex lakikirjasto, 31 (2017): 13. https://www.edilex.fi/artikkelit/17855. pdf

79. Legislative proposal for the Mining Act (HE 273/2009 vp), page 105.

80. About Tukes. Description of the mining authority. Accessed May 24,2018. http://www.tukes. fi/en/Tieto-meista/ 